\title{
Matéria Symposium 2016
}

\author{
Paulo Emílio V. de Miranda ${ }^{1}$
}

\author{
${ }^{1}$ Editor-in-Chief \\ Journal Matéria \\ E-mail: pmiranda@labh2.coppe.ufrj.br
}

The Matéria Symposium was created by a group of Latin-American scientists with the objective to gather and discuss scientific and technological themes that are relevant for the area of materials. This action has initiated with the creation in 1994 of an electronic newsletter to diffuse information on the area of materials. In 1995 a French-Latin-American congress was held in Valparaiso, Chile, where it was decided to create in the next year the Matéria Symposium and the Journal Matéria. The sequence of Matéria Symposia that were held included the following Latin-American cities: Arequipa, Peru; Bariloche and Santa Fé, Argentina; Caracas, Venezuela; Cartagena de Indias, Colombia; México City and Morelia, México; Montevideo, Uruguay; Rio de Janeiro, Brazil; Santiago, Chile. The $13^{\text {th }}$ version of the Matéria Symposium took place for the third time in Rio de Janeiro, Brazil, giving origin to the papers published in this Special Volume of the Journal Matéria, after judicious selection among all presentations made at the event and also after going through the journal's peer-reviewing process.

The event has made several innovations. Approaching the theme Materials and Energy, held two days before the symposium itself an Itinerant School of Materials, at the traditional Engineering Club, dedicated to graduate students and young researchers. The Matéria Symposium 2016 was then held at the recently created Museum of Tomorrow, located by the Guanabara Bay in Rio de Janeiro downtown. In addition to the privileged place, it had the participation of researchers from Latin America and other regions and promoted the presentation of articles under the form of digital posters. That is, poster papers were presented in TV monitors specially positioned in the museum alleys, avoiding the necessity to prepare and transport the expensive, uncomfortable and anti-ecological paper poster, making it possible to include content with the aesthetic and functional characteristics that digital presentations allow. With the complement of high-level conferences and a host of oral presentations, the event was well included in the ambient where it was held, discussing the prospects of materials for tomorrow. The Symposium Materia 2016 also nestled a meeting of the Journal Materia's Editorial Board.

The articles herein presented will allow the specialized reader to absorb and to discuss the state of the art subjects related to materials and energy. 